\title{
Pemotongan Sapi Betina Produktif di Rumah Potong Hewan di Daerah Istimewa Yogyakarta
}

\author{
N. Rasminati, S. Utomo dan D.A. Riyadi \\ Jurusan Peternakan, Fakultas Pertanian Universitas Mercu Buana, Yogyakarta
}

\begin{abstract}
ABSTRAK
Penelitian bertujuan untuk mengetahui jumlah sapi umur produktif yang dipotong di RPH maupun TPH di DIY. Materi penelitian adalah sapi-sapi yang dipotong di RPH maupun TPH di 4 kabupaten dan kodya Yogyakarta selama 1 bulan. Metode penelitian menggunakan metoda survey dan observasi langsung ke obyek (RPH dan TPH) yang telah ditentukan. Hasil penelitian menunjukkan bahwa jumlah pemotongan sapi umur produktif ( $<2$ tahun) sebanyak 28,98\%, $2-5$ tahun adalah 69,55 \% dan lebih dari 5 tahun adalah 1,44\% dengan jumlah betina 54,58\% dan jantan $32,36 \%$. Pemotongan sapi yang tidak produktif sebanyak 13,04\% yang terdiri atas 5,79\% jantan dan 7,24\% betina. Bangsa sapi PO yang dipotong sebanyak 60,36\% (125 ekor), Brahman Cross 16,42 (34 ekor), Simmental 15,94\% (33 ekor), Brangus 2,42\% (5 ekor), Limousin 4,35\% (9 ekor) dan PFH sebanyak 0,48\% (1 ekor). Persentase pemotongan sapi umur produktif adalah 86,95\% dengan jumlah betina produktif 64,25\%. Bangsa sapi yang banyak dipotong adalah sapi PO dengan jenis kelamin betina umur 2 sampai dengan 5 tahun. Dapat disimpulkan bahwa sapi betina pproduktif yang dipotong di rumah potong hewan di Yogyakarta masih cukup tinggi, hal ini akan mempengaruhi ketersediaan sumber bibit sapi potong.
\end{abstract}

Kata kunci : sapi betina produktif, pemotongan, rumah potong hewan, Yogyakarta.

\section{The productive female beef cattle slaughtering at abattoir in Yogyakarta}

\begin{abstract}
ABSTRACK
The research was conducted to know the number of the productive female beef cattle slaughtering at abattoir in DIY. All of the beef cattle which slaughtered along a month were used in this research. The result showed that the number of productive beef cattle slaughtered up to 2 years old were 28.98\%; 2 - 5 years old were 69.55\%; more than 5 years old were $1.44 \%$. The female beef cattle slaughtered were $54.58 \%$ and the male beef cattle slaughtered were $32.36 \%$. The non productive beef cattle slaughtered were $13.04 \%$ including $5.79 \%$ male and $7.24 \%$ female. The Peranakan Ongole (PO) breed slaughtered was 60.36\% (125 heads), Brahman Cross 16.42\% (34 heads), Simmental 15.94\% (33 heads), Brangus 2.42\% (5 heads), Limousine 4.35\% (9 heads) and PFH $0.48 \%$ (1 heads). The percentage of productive beef cattle slaughtering were $86.95 \%$ with female beef productive were $64.25 \%$ and the PO breed at $2-5$ years old were the most slaughtered. It could be concluded that the productive female beef cattle slaughtering at abattoir in DIY was quite high, which may influence the breed resources of beef cattle.
\end{abstract}

Key words : Productive beef cattle, slaughtering, abattoir, Yogyakarta 


\section{PENDAHULUAN}

Populasi sapi di Indonesia mengalami fluktuasi akibat kenaikan tingkat pemotongan tanpa diimbangi kenaikan kelahiran. Berbagai usaha telah dilakukan pemerintah untuk mengendalikan laju penurunan populasi sapi tanpa mengurangi pengadaan daging bagi, misalnya meningkatkan kelahiran melalui program inseminasi buatan, menekan tingkat kematian dengan penekanan masuknya penyakit dan usaha pengendalian pemotongan sapi betina produktif (Anonimus, 1989).

Sapi betina umur produktif adalah sapi betina yang masih berada dalam masa produktif yaitu berumur kurang dari lima tahun atau mempunyai gigi seri permanen di bawah empat pasang. Pemotongan sapi betina umur produktif merupakan pelanggaran, sebagaimana peraturan pemotongan hewan Staadblad No. 614 artikel 2 tahun 1936 dan instruksi bersama Menteri Dalam Negari dan Menteri Pertanian Republik Indonesia No. 18 tahun 1979, No. 66/Ins/UM/3/1979 serta SK Dirjen Peternakan No. 509/kpts/Deptan/1981 yang menyebutkan berbagai syarat pemotongn hewan besar bertanduk adalah disembelih tidak dalam hubungan dengan perusahaan atau mata pencaharian, ditimpa kecelakaan berat, karena penyakit sehingga jiwanya terancam, merupakan bahaya langsung bagi keamanan orang dan barang.

Pemerintah kemudian mengeluarkan lanjutan peraturan tersebut dalam instruksi bersama Menteri Dalam Negeri dan Menteri Pertanian Republik Indonesia tahun 1979 No. 05/ins/3/1992 tentang peraturan pencegahan dan pelarangan pemotongan ternak sapi/kerbau betina bunting dan atau sapi/kerbau betina bibit (Anonimus, 1989).

Apabila sapi betina produktif dibiarkan dipotong mengakibatkan pengadaan ternak sapi potong semakin berkurang. Selain itu karena suplai sapi potong menurun, maka harga daging sapi akan meningkat dan merangsang petani peternak untuk menjual ternaknya lebih cepat. Hal ini akan menyebabkan kelestarian ternak sapi terancam punah (Harmadji et al., 1981).
Sehubungan dengan kenyataan di atas, masalah yang perlu dikaji adalah berapa jumlah pemotongan ternak sapi umur produktif di Rumah Potong Hewan (RPH) dan Tempat Pemotongan Hewan (TPH) di wilayah Daerah Istimewa Yogyakarta (DIY). Adapun tujuan dari penelitian ini adalah untuk mengevaluasi pemotongan ternak sapi umur produktif khususnya sapi betina, agar menjadi bahan pertimbangan dalam rangka peningkatan populasi sapi potong di DIY.

\section{MATERI DAN METODE}

Penelitian dilaksanakan di RPH dan TPH yang ada di DIY, selama waktu satu bulan, yaitu bulan Juni - Juli 2004. Materi yang digunakan adalah semua ternak sapi yang dipotong di RPH dan TPH di DIY baik ternak sapi jantan maupun betina.

Data yang diperoleh yaitu jumlah, bangsa, jenis kelamin, umur dan bobot potong sapi ditabulasi, kemudian dirata-rata serta dianalisis secara deskriptif.

\section{HASIL DAN PEMBAHASAN}

\section{Asal dan Bangsa Sapi yang Dipotong}

Berdasarkan data Statistik Peternakan tahun 2003, jumlah populasi sapi potong di DIY sebanyak 23.071 ekor, konsumsi daging sebesar 4.934 ton/tahun dan jumlah pemotongan sebesar 221.564 ekor. Untuk memenuhi kebutuhan daging tersebut, berbagai usaha dilakukan dengan mendatangkan ternak sapi dari luar wilayah DIY seperti Klaten, Muntilan dan Purworejo. Selama penelitian, wilayah yang mempunyai kebutuhan daging paling tinggi tetapi populasi ternak sapi sedikit adalah Kodya Yogyakarta.

Ternak sapi yang dipotong di RPH maupun TPH selama penelitian 52\% berasal dari dalam propinsi dan $47 \%$ berasal dari daerah lain di sekitar propinsi DIY. Kebutuhan sapi potong di wilayah DIY masih disuplai dari luar propinsi, karena persediaan sapi yang layak dipotong di DIY sedikit. 
Bangsa sapi potong yang banyak dijumpai di DIY adalah Peranakan Ongole (PO), Brahman cross, Simmental, Limousin dan Brangus. Pemotongan sapi PO sebanyak $59,5 \%$ dari seluruh ternak sapi yang dipotong. Sapi PO memiliki daya adaptasi dan pertambahan bobot badan yang baik. Hal ini menyebabkan sapi PO secara luas telah diternakkan oleh masyarakat di DIY. Jumlah pemotongan terbanyak setelah sapi PO adalah sapi Brahman cross (16,6\%) dari seluruh sapi yang dipotong. Sapi Brahman cross mempunyai bentuk tubuh yang lebih besar dan tingkat pertumbuhan yang lebih cepat dibandingkan dengan sapi PO. Pemeliharaan ternak sapi di DIY kebanyakan masih bersifat tradisional, sehingga produktivitas sapi Brahman cross tidak bisa maksimal. Pemotongan sapi Simmental sebanyak 16,19\%, sedangkan sapi Brangus, Limousin dan PFH masing-masing sebesar 2,4; 4,34 dan 0,48\%. Sedikitnya jumlah pemotongan sapi tersebut sangat berhubungan dengan populasi sapi yang ada di wilayah DIY.

\section{Umur dan Bobot Potong Sapi}

Dari seluruh ternak sapi yang dipotong, pemotongan sapi jantan umur kurang dari 2 tahun sebesar 9,66\% dan betina 19,38\%. Pemotongan sapi jantan umur $2-5$ tahun $28,00 \%$ dan betina $41,50 \%$, sedangkan yang berumur lebih dari 5 tahun untuk jantan sebesar $0,50 \%$ dan betina $0,96 \%$.

Hasil penelitian menunjukkan bahwa sapi betina umur produktif yang dipotong di RPH dan TPH di DIY cukup banyak. Hal ini disebabkan karena persediaan sapi potong masih sedikit dan harga sapi betina lebih murah dibandingkan dengan sapi jantan (Anonimus, 1990 dan Harmadji et al., 1981). Selain itu dengan adanya harga sapi jantan yang lebih tinggi di pasaran, jagal dan pedagang sapi akan cenderung memilih sapi yang murah dan mudah didapat walaupun masih dalam umur produktif untuk dipotong. Pemotongan sapi betina produktif dapat mengakibatkan pengadaan ternak sapi potong akan semakin

Tabel 1. Jumlah pemotongan sapi umur produktif selama penelitian.

\begin{tabular}{|c|c|c|c|c|c|c|c|}
\hline \multirow[t]{3}{*}{ Bangsa } & \multicolumn{3}{|c|}{ Jantan } & \multicolumn{3}{|c|}{ Betina } & \multirow[t]{2}{*}{ Total } \\
\hline & \multicolumn{3}{|c|}{ Umur (tahun) } & \multicolumn{3}{|c|}{ Umur (tahun) } & \\
\hline & $<2$ & $2-5$ & $>5$ & $<2$ & $2-5$ & $>5$ & \\
\hline $\mathrm{PO}$ & 7 & 34 & 1 & 19 & 51 & 2 & 114 \\
\hline Brahman cross & 4 & 6 & 0 & 7 & 11 & 0 & 28 \\
\hline Simmental & 1 & 8 & 0 & 7 & 11 & 0 & 27 \\
\hline Brangus & 2 & 1 & 0 & 0 & 1 & 0 & 4 \\
\hline Limousin & 2 & 1 & 0 & 2 & 2 & 0 & 7 \\
\hline Jumlah & 16 & 50 & 1 & 35 & 76 & 2 & 180 \\
\hline
\end{tabular}

Tabel 2. Rata-rata bobot potong (kg) sapi yang dipotong selama penelitian.

\begin{tabular}{cccccc}
\hline \hline \multirow{2}{*}{$\begin{array}{c}\text { Umur sapi } \\
\text { (th) }\end{array}$} & PO & Brahman cross & Simmental & Brangus & Limousin \\
\cline { 2 - 6 } <2, jantan & 238,56 & 299,00 & 280,00 & 305,00 & 257,00 \\
$<$ 2, betina & 237,00 & 249,14 & 275,80 & - & 228,00 \\
2-5, jantan & 348,47 & 356,67 & 343,40 & 360,00 & 378,00 \\
2-5, betina & 332,44 & 363,25 & 342,58 & 351,50 & 322,00 \\
$>$ 5, jantan & 510,00 & - & - & - & - \\
$>$ 5, betina & 486,50 & - & - & - & - \\
\hline Rerata & 358,82 & 317,01 & 310,45 & 338,83 & 296,25 \\
\hline
\end{tabular}


berkurang, sehingga harga daging sapi meningkat. Hal ini akan merangsang peternak untuk menjual ternaknya lebih awal. Jumlah sapi produktif yang dipotong di RPH maupun TPH di DIY selama penelitian adalah 86,95\% terdiri dari 37,22\% jantan dan 62,78\% betina. Sedangkan sapi yang tidak produktif yang dipotong sejumlah $13,05 \%$ yang terdiri dari $44,44 \%$ jantan dan $55,56 \%$ betina. Sapi yang tidak produktif adalah sapi yang tidak menguntungkan secara ekonomis baik untuk usaha penggemukan, ternak kerja maupun reproduksi. Sapi tidak produktif ini memiliki eksterior yang jelek, umur sudah tua, penurunan kemampuan reproduksi dan sapi yang sakit.

Selama penelitian, bobot terendah dari sapi yang dipotong adalah $237 \mathrm{~kg}$ sedangkan bobot tertinggi adalah $510 \mathrm{~kg}$ (Tabel 2.)

Hasil penelitian menunjukkan bahwa sapi PO merupakan sapi yang paling banyak dipotong dengan bobot potong rata-rata 358,82 kg. Hasil ini tidak sesuai dengan pendapat Reksohadiprodjo (1984) yang menyatakan bahwa sapi PO sebaiknya dipotong setelah mencapai bobot potong antara $368-408 \mathrm{~kg}$. Pemotongan sapi sebelum bobot potong maksimal tercapai ini dapat terjadi, karena petani di daerah Yogyakarta masih memelihara ternak secara tradisional dan hanya sebagai usaha sampingan. Para peternak belum memberikan perhatian pada ternak sepenuhnya, terutama dalam pemeliharaan, pemberian pakan dan bibit yang digunakan. Bibit ternak sapi yang digunakan masih seadanya, karena belum dilakukan seleksi secara terarah.

Pemotongan sapi yang belum waktunya dapat terjadi karena para pedagang atau jagal harus memenuhi kebutuhan konsumen akan daging sapi yang cukup tinggi. Selain itu kesadaran peternak tentang efek negatif dari penjualan ternak umur produktif masih sangat kurang. Soedarmono (1983) menyatakan bahwa keadaan sosial ekonomi peternak yang masih rendah dan kurangnya petugas maupun ulah pedagang menghindar dari pengawasan, mengakibatkan ternak umur produktif dapat lolos ke arah konsumen. Jika ternak tersebut lolos, akan diusahakan untuk dipotong karena ternak tersebut tidak mungkin dikembalikan ke daerah produsen atau diternakkan sebagai bibit, sehingga dengan berbagai upaya jagal akan tetap memotong ternak tersebut.

Hasil penelitian menunjukkan bahwa rata-rata persentase karkas untuk sapi PO, Brahman cross, Simmental, Brangus dan Limousin berturut-turut adalah 46,36; 44,89; 44,90; 45,39 dan 44,67\%. Persentase karkas sangat dipengaruhi oleh bobot potong ternak. Kenaikan bobot potong akan cenderung meningkatkan persentase karkas yang diikuti dengan persentase daging dan tulang. Berarti dengan bobot potong yang lebih tinggi akan menghasilkan karkas yang tinggi pula.

\section{Prediksi Kebutuhan Ternak Sapi di DIY}

Kebutuhan daging di DIY tahun 2003 adalah 36.860 ton/tahun dengan produksi daging sapi 4.934 ton/tahun, sedangkan pemotongan sapi sebesar 23.071 ekor/tahun (Statistik Peternakan, 2003). Hal ini berarti produksi daging rata-rata per ekor $213 \mathrm{~kg}$ setara dengan sapi yang terpotong dengan bobot potong 471,76 kg. Fakta di lapangan menunjukkan bahwa rata-rata bobot potong sapi adalah 324,27 kg, sehingga dibutuhkan lebih banyak sapi yang dipotong setiap tahunnya untuk memenuhi kebutuhan daging.

Menurut data statistik tahun 2003, propinsi DIY mempunyai populasi ternak sapi potong sebesar 221.564 ekor dan konsumsi protein hewani yang berasal dari daging sebesar $5,52 \mathrm{~kg} / \mathrm{kapita} / \mathrm{tahun}$. Jika kontribusi daging sapi hanya $13,38 \%$, berarti konsumsi daging sapi adalah $0,73 \mathrm{~kg} / \mathrm{kapita} / \mathrm{tahun}$. Jumlah penduduk di DIY 3.163 .000 orang, sehingga akan dibutuhkan daging sekitar 2.302,67 ton. Apabila daging tersebut dipenuhi dengan memotong ternak sapi yang ada di wilayah DIY, akan dibutuhkan 23.719 ekor sapi per tahun, sehingga dapat diprediksi dalam $9-10$ tahun mendatang, populasi ternak sapi di DIY akan terkuras dan punah apabila pemotongan sapi betina produktif dilakukan terus menerus. Berdasarkan hal tersebut, perlu dilakukan 
peningkatan populasi ternak dan kualitas genetiknya dengan mencegah pemotongan betina umur produktif dan perbaikan pelaksanaan IB di lapangan. Diharapkan di propinsi DIY di masa-masa mendatang akan tersedia sumber bibit yang potensial untuk mencegah terkurasnya populasi ternak sapi potong.

\section{KESIMPULAN}

Pemotongan sapi umur produktif di propinsi DIY mencapai 86,95 \% dengan jumlah pemotongan sapi betina produktif $64,25 \%$. Sapi yang paling banyak di potong adalah bangsa sapi PO dengan jenis kelamin betina umur $2-5$ tahun.

\section{DAFTAR PUSTAKA}

Anonimus, 1989. Kebijakan Operasional Pembangunan Peternakan Dalam Pelita V. Dirjen Peternakan, Deptan, Jakarta.

Anonimus, 1990. Sapi Potong dan Kerja. Kanisius, Yogyakarta.

Badan Pusat Statistik, 2003. Statistik Peternakan Tahun 2003. Dirjen Bina Produksi Peternakan, Departemen Pertanian, Jakarta.

Harmadji, S. Gamblong dan M.cGatot, 1981. Pengendalian Pemotongan Sapi Betina Umur Produktif dan Permasalahannya. Kertas Kerja Seminar Penelitian Peternakan. Bogor.

Reksohadiprodjo, S., 1984. Pengantar Ilmu Peternakan Tropik. BPFE. Yogyakarta.

Soedarmono, 1983. Upaya Peningkatan Populasi Ternak dengan Mengendalikan Terjadinya Pemotongan Sapi dan Kerbau Betina Produktif. Dirjen Peternakan, Deptan, Jakarta. 